\title{
Robustness or resilience? Managing the intersection of ecology and engineering in an urban Alaskan fishery
}

\author{
Meagan B. Krupa ${ }^{1}, \underline{F}_{\text {. Stuart Chapin, } \text { III }^{2} \text { and Amy L. Lovecraft }}{ }^{2}$
}

\begin{abstract}
Systems theories of robustness and resilience, which are derived from engineering and ecology, respectively, have been increasingly applied to social-ecological systems (SESs). Social-ecological robustness has been applied primarily to management of physical dimensions of SESs (e.g., water management) and resilience to management of ecological dimensions of SESs (e.g., rangelands). However, cases of highly engineered systems have yet to be adequately evaluated by either approach. We find the robustness framework serves to better explain management options of a highly engineered, ecologically-based SES, the lower Ship Creek fishery in Anchorage, Alaska, USA. Robustness applies well to this system because its dynamics are highly engineered through both structures and institutions. Even the salmon are products of a hatchery fishery that operates independently of many ecological variables and feedbacks within the system. However, robustness theory has yet to develop a prescriptive method for management that can assist practitioners. We conclude by applying Ostrom's design principles to the system dynamics to assess opportunities for increasing the robustness of this urban fishery.
\end{abstract}

Key Words: hatchery; robustness theory; salmon; social-ecological systems; stream management; urban fishery

\section{INTRODUCTION}

Every summer, residents and visitors gather for a unique fishing experience on a creek in downtown Anchorage, Alaska. Surrounded by industrial yards, the state's railroad, interlocking road systems, and the city's port, the Ship Creek fishery seems a paradoxical entity. It functions, for thousands of visitors and residents, as a wildlife experience within a highly urbanized locale.

What many people do not realize is that their fishing experience is the product of a highly engineered fishery, stocked by a hatchery and maintained by a complex network of institutional arrangements. The challenges of this urban fishery are not unique. Increasing urbanization in the lower Pacific Northwest has pushed wild salmon populations to the brink of extinction (Netboy 1980, Nehlsen et al. 1991, Cone and Ridlington 1996, Huntington et al. 1996, National Research Council 1996, Gresh et al. 2000). Widespread public support has leveraged millions of restoration dollars to prevent the loss of salmon populations, but still they are disappearing (Lee 1993, McGinnis 1994, 1995). Although the reasons for this failure are complicated, one of the likely main drivers is the failure to address the underlying socioeconomic causes of the biophysical symptoms. Numerous studies have explored management in social-ecological systems (SESs; Ostrom 2009, Anderies and Janssen 2011, Bodin and Tengö 2012). Most of these studies have focused on identifying the ecological and social sources of resilience that would enable the system to persist in its current state or the management techniques that might increase the system's resilience in the face of uncertainty and shocks to the system. Whereas the goals of this study are similar, the semi-engineered characteristics of an urban fishery SES are different. We examine the lower Ship Creek fishery SES because it contains clearly identifiable interactions between the biological and social systems.

The complex interactions between the components within SESs have also been studied in commercial fisheries (McHugh 1975, Finlayson and McCay 1998, Acheson 2003, Augerot and Smith
2010), but urban sport fisheries have received little attention. Ours is the first study to apply robustness theory to an engineered, biological resource. The fishery under examination includes hatchery-produced chinook salmon (Oncorhynchus tshawytscha) and coho salmon (Oncorhynchus kisutch) and encompasses the last $1.45 \mathrm{~km}$ of Ship Creek, extending from the Knik Arm power plant (KAPP) dam to the mouth of the creek at Cook Inlet. Lower Ship Creek experiences a tidal range of $11.3 \mathrm{~m}$, which poses engineering challenges for the construction and maintenance of public infrastructure and streambank stabilization projects.

Ship Creek is Anchorage's original 1912 town site and once supplied Alaska's aboriginal residents, the Dena'ina, with abundant salmon runs. Historically, Ship Creek supported wild runs of all five Pacific salmon species (chinook, coho, pink [Oncorhynchus gorbuscha], chum [Oncorhynchus keta], and sockeye [Oncorhynchus nerka]), as well as Dolly Varden (Salvelinus malma), rainbow trout (Salmo gairdneri), and stickleback (Gasterosteus aculeatus) (ADFG 2007). Chinook and coho salmon are anadromous, beginning and ending their lives in freshwater streams, with adult migration to the marine environment, where they mature. Chinook spend two months to two years in freshwater before migrating to the ocean, where they spend an average of two to four years before returning to their natal streams. Chinook prefer large, deep streams and are the largest of the salmon species, with adults exceeding $18 \mathrm{~kg}$. Coho are a smaller species, with an average weight of $3.6 \mathrm{~kg}$, and prefer smaller streams and tributaries with stable gravel substrates. Coho juveniles rear in freshwater for up to 15 months, migrate to the ocean for two years, then spawn in freshwater at the age of three (National Marine Fisheries Service: chinook salmon, http://www. nmfs.noaa.gov/pr/species/fish/chinooksalmon.htm; coho salmon, http://www.nmfs.noaa.gov/pr/species/fish/cohosalmon.htm). The run sizes of the original five salmon populations are unknown, but today's hatchery-supported runs greatly exceed historical numbers (ADFG 2007). 
Today's lower Ship Creek fishery is a semi-engineered system sitting at the crossroads between wilderness and concrete. Ship Creek was first stocked with chinook salmon smolts in 1966 and coho smolts in 1968 from the Elmendorf Hatchery (ADFG 2007). Declining wild runs of chum and pink salmon and Dolly Varden still spawn in the creek, but their numbers are undocumented. Sport fishing for salmon is permitted within the last $1.45 \mathrm{~km}$ of the creek, from the KAPP dam to the mouth (ADFG 2007).

In 2007, the Mayor of Anchorage, Mark Begich, identified the revitalization of Ship Creek as one of the top priorities of his administration (U.S. Mayor Newspaper 2008). In 2013, Mayor Dan Sullivan announced his intention to redesign Ship Creek with a new master plan (Ship Creek redevelopment: http://www.muni. org/Departments/Mayor/Pages/ShipCreek.aspx). Many residents learn how to fish on Ship Creek. Local businesses recognize the economic potential of the SES and are interested in drawing more people to Ship Creek. An annual average (1996-2005) of 47,000 angler days of effort produces an average catch of 8900 chinook salmon and 16,500 coho salmon (ADFG 2007).

Although this easily accessed fishery provides large socioeconomic benefits, it also imposes the external costs commonly associated with common-pool resources (Ostrom 1990, Schlüter and Pahl-Wostl 2007). Although the Alaska Department of Fish and Game (ADFG) has increased the release of hatchery fish over the years, no provisions have been made to support the fishery's infrastructure (Krupa and Valcic 2011). The lack of public infrastructure such as bathrooms, fish cleaning stations, and garbage cans, and an increase in trespassing, illegal fishing, angler conflicts, and erosion create annual problems within what has come to be called a combat fishery (Alaska Railroad Corporation 1999, Anchorage Waterways Council 2007).

Over the past century, lower Ship Creek has been transformed from a seasonally inhabited, forested river with abundant wild salmon runs to a channelized, dammed, polluted, and hatcherystocked urban system. It is therefore highly unlikely that the processes that allowed the original wild populations to selfregulate account for its current dynamics. Since 1990, the Alaska Department of Environmental Conservation has listed Ship Creek from the Glenn Highway bridge to its mouth at Cook Inlet as a 303(d) Impaired Waterbody because of the presence of petroleum hydrocarbons, oil, grease, fecal coliform bacteria, and biological community alteration from urban runoff and industrial spills (Alaska Department of Environmental Conservation 2004). In 2007, the presence of disease (Myxobolus cerebralis) in Ship Creek (Arsan 2006) forced ADFG's Elmendorf Hatchery to limit the introduction of hatchery fish to land-locked systems. To prevent further losses in production related to changes in water quantity or quality, the state secured funding to construct the Jack Hernandez Hatchery Facility, which uses well-water reuse systems.

What methodological approach can best help managers delineate the socioeconomic causes of biophysical degradation within an urban SES? Can such an approach be used to achieve better the goals identified by users and public infrastructure providers? We propose that the robustness framework (Anderies et al. 2004, Janssen and Anderies 2007, Janssen et al. 2007) and Ostrom's $(1990,2007)$ institutional design principles can help contextualize the biophysical problems associated with the management of sport fisheries and allow managers to understand better the character of and interactions between the components of this semi-engineered, urban SES.

Two of the most common theories within SES studies are resilience and robustness. Unlike the ecological resilience perspective, which often considers human activities as perturbations of an ecological system, robustness literature considers the development of institutional feedback loops by people responding to perturbation as part of an SES (Janssen and Anderies 2007). Robust systems are generally characterized as partly-designed systems, with both self-organized and designed components (Anderies et al. 2003). We use this definition of robustness rather than considering robustness to be synonymous with ecological resilience (Levin and Lubchenco 2008). Robustness explicitly links the dynamics of systems to performance measures (Anderies et al. 2013). Crafted institutional arrangements aim to stimulate and support a particular performance of an SES, just as engineers design systems to meet certain design criteria (Janssen and Anderies 2007). We apply a robustness framework, rather than ecological resilience theory, because robustness encompasses the particular attributes of this SES, which has relatively weak feedbacks between its designed and self-organized components. However, most previous robustness assessments have addressed the design and management of physical components of systems such as dams and irrigation systems to manage water (Anderies et al. 2004, Janssen and Anderies 2007, Janssen et al. 2007), whereas management of ecological dynamics has relied more frequently on a resilience framework (e.g., Walker et al. 2004, 2006, Anderies et al. 2005).

When Ostrom (1990) derived a set of design principles from studies of small-scale, long-enduring institutions for governing common-pool natural resources, she did not initially connect them with the robustness concept. These principles were based on years of fieldwork and case studies of common-pool resources that ranged from simple and self-contained to complex and linked systems and have been well tested over the last two decades (de Moor et al. 2002, Kaijser 2002, Dietz et al. 2003). Ostrom later paired the concept of robustness with her initial design principles for common-pool resources by stating that an SES is likely to be robust if it meets many (but perhaps not all) of these principles (Ostrom 1999, 2002, 2005, Ostrom et al. 2003).

As applied to SESs, robustness is defined as "the maintenance of some desired system characteristics despite fluctuations in the behavior of its component parts or its environment" (Carlson and Doyle 2002). An SES that is subjected to a particular type and degree of variability may become highly optimized to tolerate that variability in ways that make it more fragile or sensitive when confronted with novel disturbances (Carlson and Doyle 2002, Anderies and Janssen 2011). Therefore, robustness emphasizes the cost-benefit trade-offs associated with systems designed to cope with uncertainty (Anderies et al. 2004, Janssen and Anderies 2007). Perceived environmental problems, social conflicts, and economic fluctuations all produce challenges, but with the proper infrastructure, no single shock is likely to bring ruin to a robust system. The basic premise for a robustness approach is that human actions taken in response to environmental conditions constitute 
Table 1. Cross-scale linkages of user groups, the resource, public infrastructure providers, and rules and regulations.

\begin{tabular}{ll}
\hline \hline Desired outcome & \multicolumn{1}{c}{ Interested social actors } \\
\hline Restored fish passage and habitat & Alaska Department of Fish and Game, Anchorage Waterways \\
& Council, National Marine Fisheries Service, U.S. Fish and \\
Wildlife Service, anglers & Alaska Department of Environmental Conservation, Alaska \\
Improved water quality & Railroad Corporation, Anchorage Waterways Council, U.S. \\
& Environmental Protection Agency, anglers \\
& Anchorage Waterways Council, U.S. Fish and Wildlife Service, \\
anglers & \\
Increased stream/riparian function & Alaska Department of Fish and Game, Anchorage Waterways \\
& Council, Municipality of Anchorage, U.S. Fish and Wildlife \\
Angling opportunities & Service, anglers \\
& Alaska Railroad Corporation, Anchorage Waterways Council \\
& Alaska Railroad Corporation \\
Decreased erosion & Alaska Department of Fish and Game \\
Safe access & Municipality of Anchorage \\
Maximized harvest and minimized maintenance &
\end{tabular}

feedbacks, and feedback systems are known to exhibit inherent robustness-fragility trade-offs (Carlson and Doyle 2002).

Because urban hatchery fisheries are partly-designed systems that contain both engineered (i.e., hatchery fish) and biological (i.e., nutrient cycling) components, robustness is a fitting framework for this particular case study. SES robustness depends largely on the capacity of its public infrastructure providers to respond to coinciding occurrences of economic, social, and ecological changes (Anderies et al. 2004). When one resource collapses, managers have the ability to achieve a desired outcome through the substitution of another valued good. Management decisions rely on feedbacks between both slow (e.g., evolution, long-lived institutions) and fast (e.g., pollution event, organizational collapse) variables (Carpenter and Gunderson 2001). Managers are able to make predictions based on slow variables, but the selforganizing properties of SESs cause increased uncertainty over time (Levin 2000). It is therefore important to examine selforganized and engineered components individually when assessing robustness. It is also important to acknowledge the dynamic nature of SESs. There is no final solution for managing complex governance problems like those on Ship Creek because the interacting variables are constantly in flux. Ostrom's (2007) diagnostic approach for going beyond panaceas recognizes the limitations of a single solution and proposes that the development of nested conceptual maps will allow managers to address uncertainties.

The lower Ship Creek fishery has the potential to take pressure off other wild fish stocks while providing the community with a food source and recreational opportunities. After exploring the dynamics of the fishery, we suggest robustness opportunities that could save Anchorage-area agencies, businesses, and organizations time and money. This qualitative case study analysis can serve as a guide to managers and users of other urban ecosystems throughout the United States and abroad, including the lower Pacific Northwest.

\section{METHODS}

We use three steps to help managers better address the causes of biophysical degradation. First, we identify and describe the relevant social components using Anderies et al.'s (2004) framework. Then, we outline the current and desired outcomes, as formally defined by resource users and public infrastructure providers (PIPs). Finally, we discuss the interactions within and between these systems.

\section{Social components}

The social components that most directly influence the fishery are the PIPs and resource users, which interact within a complex network of private land ownerships and federal and state jurisdictions. PIPs are the agencies that directly or indirectly support the operation and maintenance of the fishery by providing services such as fish production or trash removal services. These agencies include ADFG, Alaska Department of Environmental Conservation, Alaska Railroad Corporation, Anchorage Waterways Council, U.S. Environmental Protection Agency (EPA), Municipality of Anchorage, National Marine Fisheries Service, and U.S. Fish and Wildlife Service. Resource users are the anglers that consume the catch of fish and contribute to the public infrastructure providers via annual fees.

Because agencies work within existing and sometimes conflicting mandates, and anglers have different needs, it is beneficial to examine carefully the formally desired outcomes of both anglers and PIPs.

\section{Desired outcomes}

Although each of the public infrastructure entities works under a different mission statement, they share goals with each other and with the anglers (Table 1). Thus, a broadly desirable outcome may be possible without having to address the major trade-offs often associated with common-pool resources. The goals include restored fish and wildlife habitat, improved water quality, increased stream/riparian function, angling opportunities, decreased erosion, safe access, maximized harvest, minimized maintenance, and increased economic activities. 
Table 2. Public infrastructure providers' desired social and ecological components of the lower Ship Creek fishery.

\begin{tabular}{|c|c|c|c|}
\hline Linkage & Current outcome & Desired outcome & Opportunities for robustness \\
\hline \multirow[t]{8}{*}{$\begin{array}{l}\text { Anglers-salmon-- } \\
\text { PIPs } \dagger\end{array}$} & $\begin{array}{l}\text { Degraded fish and wildlife } \\
\text { habitat }\end{array}$ & Restored fish passage and habitat & $\begin{array}{l}\text { Proportional equivalence between } \\
\text { benefits and costs }\end{array}$ \\
\hline & Poor water quality & Improved water quality & $\begin{array}{l}\text { E.g., ADFGt pays for the public } \\
\text { infrastructure and restoration needs } \\
\text { within the fishery }\end{array}$ \\
\hline & Poor stream/riparian function & Increased stream/riparian function & Collective-choice agreements \\
\hline & Angling opportunities & Angling opportunities & $\begin{array}{c}\text { E.g., ADFG includes angler groups } \\
\text { and other PIPs within its annual } \\
\text { planning process }\end{array}$ \\
\hline & Streambank erosion & Decreased erosion & $\begin{array}{c}\text { Increased user and biophysical } \\
\text { monitoring }\end{array}$ \\
\hline & Unsafe access & Safe access & $\begin{array}{l}\text { E.g., include monitory requirement } \\
\text { in future restoration projects to } \\
\text { quantify benefits and impacts }\end{array}$ \\
\hline & $\begin{array}{c}\text { Lack of economic } \\
\text { development }\end{array}$ & $\begin{array}{l}\text { Maximized harvest and minimized } \\
\text { maintenance }\end{array}$ & \\
\hline & & Increased economic opportunity & \\
\hline \multirow[t]{4}{*}{ Anglers-PIPs } & Angler protests & Angling opportunities & Collective-choice agreements \\
\hline & Unsafe access & Decreased erosion & $\begin{array}{c}\text { Increased user and biophysical } \\
\text { monitoring }\end{array}$ \\
\hline & Illegal fishing & Safe access & \\
\hline & $\begin{array}{c}\text { Lack of economic } \\
\text { development }\end{array}$ & $\begin{array}{l}\text { Maximized harvest and minimized } \\
\text { maintenance }\end{array}$ & \\
\hline \multirow[t]{2}{*}{ Anglers-anglers } & $\begin{array}{l}\text { Unsafe access } \\
\text { Angler conflicts }\end{array}$ & $\begin{array}{l}\text { Increased economic opportunity } \\
\text { Restored fish passage and habitat } \\
\text { Improved water quality }\end{array}$ & $\begin{array}{l}\text { Collective-choice agreements } \\
\text { Increased user and biophysical } \\
\text { monitoring }\end{array}$ \\
\hline & & $\begin{array}{c}\text { Increased stream/riparian function } \\
\text { Angling opportunities } \\
\text { Decreased erosion } \\
\text { Safe access }\end{array}$ & \\
\hline \multirow[t]{3}{*}{ Anglers-R\&R } & Strain on Salmon Resource & $\begin{array}{c}\text { Maximized Harvest \& Minimized } \\
\text { Maintenance }\end{array}$ & Collective-choice agreements \\
\hline & Frequent Closures & Angling Opportunity & $\begin{array}{l}\text { Increased user and biophysical } \\
\text { monitoring }\end{array}$ \\
\hline & $\begin{array}{l}\text { Unsafe Access } \\
\text { Illegal fishing }\end{array}$ & Safe Access & \\
\hline \multirow[t]{3}{*}{ PIPs-Salmon } & New Hatchery Facility & $\begin{array}{c}\text { Maximized Harvest \& Minimized } \\
\text { Maintenance }\end{array}$ & $\begin{array}{l}\text { Proportional equivalence between } \\
\text { benefits and costs }\end{array}$ \\
\hline & $\begin{array}{c}\text { Increased Number of Angler } \\
\text { Days }\end{array}$ & Angling Opportunity & Collective-choice agreements \\
\hline & $\begin{array}{c}\text { Lack of Support Facilities } \\
\text { (fish cleaning stations, } \\
\text { restrooms) }\end{array}$ & & $\begin{array}{l}\text { Increased user and biophysical } \\
\text { monitoring }\end{array}$ \\
\hline \multirow[t]{4}{*}{ PIPs-PIPs } & $\begin{array}{c}\text { Poorly Designed restoration } \\
\text { projects }\end{array}$ & Restored Fish Passage \& Habitat & $\begin{array}{l}\text { Proportional equivalence between } \\
\text { benefits and costs }\end{array}$ \\
\hline & No master plan & Improved Water Quality & Collective-choice agreements \\
\hline & $\begin{array}{l}\text { Lack of Economic } \\
\text { Development }\end{array}$ & Increased Stream/Riparian Function & $\begin{array}{l}\text { Increased user and biophysical } \\
\text { monitoring }\end{array}$ \\
\hline & & Angling Opportunity & \\
\hline
\end{tabular}




\begin{tabular}{|c|c|c|c|}
\hline \multirow{3}{*}{$\begin{array}{l}\text { PIPs-rules and } \\
\text { regulations }\end{array}$} & Unsafe angler access & $\begin{array}{c}\text { Decreased Erosion } \\
\text { Safe Access } \\
\text { Maximized Harvest \& Minimized } \\
\text { Maintenance } \\
\text { Increased Economic Opportunities } \\
\text { Angling opportunities }\end{array}$ & Collective-choice agreements \\
\hline & Lack of sufficient monitoring & Safe access & $\begin{array}{c}\text { Increased user and biophysical } \\
\text { monitoring }\end{array}$ \\
\hline & & $\begin{array}{l}\text { Maximized harvest and minimized } \\
\text { maintenance }\end{array}$ & \\
\hline
\end{tabular}

$\uparrow$ Public infrastructure providers.

tAlaska Department of Fish and Game.

\section{Interactions}

Despite the mutually desired outcomes, many of the PIPs are not currently working to achieve them (Table 2). By examining specific interactions between the PIPs, anglers, salmon, and rules and regulations, we can use Ostrom's design principles (1990) and diagnostic approach (2007) to identify opportunities for increased SES robustness (Anderies et al. 2004).

\section{ANALYSIS OF SHIP CREEK SOCIAL-ECOLOGICAL SYSTEM}

Using Ostrom's (1990) design principles, the robustness of this SES can be assessed based on the ability of the PIPs to create a flexible yet inclusive management structure that allows the SES to adapt to changes in angler numbers, stream conditions, and development pressures (Table 2).

\section{Clearly defined boundaries}

The ADFG clearly defines the boundaries of the salmon fishery as $1.45 \mathrm{~km}$ long, from $15 \mathrm{~m}$ below the KAPP dam to the mouth of the creek at Cook Inlet. Anyone who has purchased a sport fishing license from ADFG and abides by the fishing regulations has a right to fish the creek.

\section{Graduated sanctions}

Graduated sanctions for the lower Ship Creek fishery include a bail schedule for sport fish violations that takes into account the severity of the violation.

\section{Conflict-resolution mechanisms}

Ship Creek anglers and officials have access to the Alaska State Troopers or the Alaska Railroad Corporation to resolve conflict.

\section{Minimal recognition of rights to organize}

The rights to organize are present within this system. If users wanted to create their own institution, they could do so and claim rights to participate in management decisions.

\section{Proportional equivalence between benefits and costs}

There is a disproportionate relationship between the benefits and costs of this SES (Krupa and Valcic 2011). The costs of maintaining this fishery are currently not accounted for, whereas the benefits are routinely advertised. The ADFG has not responded to the mounting costs by limiting the fishery's total allowable catch (TAC). In fact, the number of angler user days has increased each year (ADFG 2014).

\section{Collective-choice arrangements}

There is a limited collective-choice arrangement on Ship Creek between the resource users and the ADFG, but other affected PIPs are excluded from this process.

\section{Monitoring}

Although the ADFG, Alaska State Troopers, and Alaska Railroad Corporation all monitor user licensing and behavior on Ship Creek, enforcement remains a problem in this easily accessed fishery. The U.S. Geological Survey (USGS) currently monitors the quantity of water in Ship Creek at two gauge stations. The Anchorage Waterways Council, EPA, and Alaska Department of Environmental Conservation monitor the water quality of Ship Creek. Because of a lack of continuous biophysical monitoring of water quality and quantity, the ecological (and resulting social and economic) costs and benefits of restoration projects are largely unknown and are therefore a source of conflict among PIPs.

\section{Opportunities}

By evaluating the strengths and weaknesses of the relationships between the public PIPs and anglers, this SES fails to meet three of Ostrom's (1990) seven design principles. The SES does not have (1) a proportional equivalence between benefits and costs, (2) collective-choice agreements, and (3) sufficient user and biophysical monitoring (Table 2). The lack of these components threatens the robustness of the SES. The need for both proportional equivalence between benefits and costs and collective-choice agreements addresses the problems of free riding and subtractability of use through the creation of rules (Anderies et al. 2004), but fails to address the problem of enforcing these rules. User and biophysical monitoring play vital roles in enforcing these rules and increasing SES robustness. If addressed in unison, these three opportunities could increase SES robustness and increase sustainability of the resource.

To address these opportunities to enhance robustness, the Municipality of Anchorage's Watershed and Natural Resources Advisory Commission could bring the PIPs together to discuss the issue of robustness in its entirety and specifically address the implementation of mechanisms to fill each of the above gaps. Currently, the commission is an advisory team that provides technical advice and guidance to help facilitate coordinated and collaborative local, state, federal, and private sector watershed 
and natural resources stewardship. If the task force formalized its existence within the municipal structure as a board with authority to coordinate implementation, it could assume an increased role in watershed management and create more opportunities for multi-agency involvement in decision-making and implementation.

\section{Creating a proportional equivalence of benefits and costs}

Studies of irrigation systems have shown that appropriation and provisions are two major sources of collective-action problems (Tang 1992, Lee 1994). Appropriation problems are time independent and result from the allocation structure of a limited resource (Ostrom 1990). Provision problems are time dependent and result from the allocation structure of responsibilities for building, repairing, or maintaining resource systems, as well as the appropriators' well-being (Ostrom 1990). Ship Creek experiences problems of inappropriate provision, leading to ineffective appropriation, i.e., a provision-appropriation interaction. The high production of hatchery fish (provision) and the associated increases in use (appropriation) are causing ecological and social problems within this SES that threaten the robustness of both production and use. The first step in creating a proportional equivalence of benefits and costs would be for the ADFG to address the appropriation problem either by decreasing the TAC until adequate public infrastructure is in place to prevent further degradation to existing infrastructure and stream conditions or by giving actors in the system the choice of either reducing TAC or increasing infrastructure.

Provision problems within this SES exist because of inequities and confusion in the assignment of resource system responsibilities. The ADFG currently benefits from the user fees provided by the fishery but pays very few of its infrastructure costs (Krupa and Valcic 2011). A more equitable cost-sharing framework such as that established by a group of irrigators in Japan (Sarker and Itoh 2001) would enable the agencies to share the project costs associated with future TAC levels.

\section{Developing collective-choice agreements}

Currently, there is a communication gap between the PIPs and users. This gap could lead to the construction of infrastructure that does not match the needs of the users. The creation of a linkage between PIPs and users has proven to be an important component of robust SESs (Levine 1977, Moore 1989, Lam 1996). Although the individual characteristics of long-lasting, commonpool resource SESs differ greatly, they all have resource users linked to public infrastructure providers (Coward 1979, Siy 1982, Martin and Yoder 1983, Laitos 1986, Maass and Anderson 1986, Blomquist 1992).

The ADFG could bridge the existing gap between PIPs and users. The inclusion of PIPs into the annual hatchery planning process would enable the development of collective-choice agreements that would define specific roles in the implementation of relevant improvements and maintenance efforts.

\section{Increasing user and biophysical monitoring}

Increased user and biophysical monitoring would protect the investment of infrastructure on lower Ship Creek. Regular patrols would increase user safety through the strict enforcement of existing ADFG fishing and Alaska Railroad Corporation trespassing regulations. The Anchorage Waterways Council and USGS currently monitor water quality and quantity, but each experiences funding shortages that interrupt monitoring efforts. To prevent future monitoring gaps, the EPA and Alaska Department of Environmental Conservation could develop a long-term funding plan to support the Anchorage Waterways Council's water monitoring efforts and the USGS's water gauging at the two existing sites. PIPs could also include a monitoring component in every future project design.

Because of the occurrence of night-time violations and nonpoint source pollution within this SES, managers should be aware that monitoring and enforcement efforts may become economically inefficient (Colby 1995, Berkes and Folke 1998, Heal 1998). Combining user education and outreach with monitoring and enforcement may be a more cost-effective solution.

\section{DISCUSSION}

As more ecological systems encounter engineering to optimize or restore their functions, robustness theory can help navigate the complex feedbacks and guide management practices. Urban systems possess great social, economic, and ecological value and can be maintained despite uncertain conditions, but this will also require a paradigm shift among the PIPs.

Lower Ship Creek is neither engineered nor wild. It is a unique combination of biophysical components interacting with an engineered resource in an urban setting. The current challenges within this SES are the result of PIPs' failures to address both of these components in their management efforts.

The robustness framework works well for analyzing the lower Ship Creek SES because of the fishery's highly engineered infrastructure. Even the salmon biology is engineered in the sense that the production of salmon is driven primarily by the economics and policy of the hatchery. Salmon production has not yet been strongly influenced by biological feedbacks that characterize most ecological dimensions of SESs.

The challenges of regulating an urban, engineered, combat fishery are real but not insurmountable. Urban managers can use the design principles (Ostrom 1990, 2007) within the robustness framework to distinguish the socioeconomic and ecological components of engineered systems and use this knowledge to maintain engineered systems more effectively. Future research into the similarities between interacting PIPs and resource users in other urban engineered SESs as well as this SES's ability to meet the design criteria would provide further insight into the governance arrangements that promote robustness.

Responses to this article can be read online at: http://www.ecologyandsociety.org/issues/responses. $\mathrm{php} / 6274$

\section{Acknowledgments:}

We thank the Alaska Department of Environmental Conservation, Alaska Department of Fish and Game, Alaska Railroad Corporation, Anchorage Waterways Council, U.S. Environmental Protection Agency, Municipality of Anchorage, National Marine Fisheries Service, and U.S. Fish and Wildlife Service for their contributions. 


\section{LITERATURE CITED}

Acheson, J. M. 2003. Capturing the commons: devising institutions to manage the Maine lobster industry. University Press of New England, Lebanon, New Hampshire, USA.

Alaska Department of Environmental Conservation. 2004. Total maximum daily load (TMDL) for fecal coliform in the waters of Ship Creek in Anchorage, Alaska. Alaska Department of Environmental Conservation, Anchorage, Alaska, USA. [online] URL: http://dec.alaska.gov/water/tmdl/pdfs/final $\% 20 \mathrm{fc} \% 20 \mathrm{tmdl} \%$ 20ship $\% 20$ creek $\% 205-12$.pdf. $^{\circ}$

Alaska Department of Fish and Game (ADFG). 2007. Ship Creek development discussion points. Sport Fish Division, Alaska Department of Fish and Game, Anchorage, Alaska, USA.

Alaska Department of Fish and Game (ADFG). 2014. Region II statewide stocking plan for recreational fisheries. Alaska Department of Fish and Game, Anchorage, Alaska, USA. [online] URL: http://www.adfg.alaska.gov/static/fishing/pdfs/ hatcheries/14region2.pdf.

Alaska Railroad Corporation. 1999. Annual report. Alaska Railroad Corporation, Anchorage, Alaska, USA. [online] URL: https://www.alaskarailroad.com/Portals/6/pdf/corp/Corporate99anrpt. pdf.

Anchorage Waterways Council. 2007. Ship Creek unplugged program projects. Anchorage Waterways Council, Anchorage, Alaska, USA. [online] URL: http://anchoragecreeks.org/pages/ shipcreek about.php?searchresult=1\&sstring=Ship + Creek + Unplugged\#wb 10.

Anderies, J. M., C. Folke, B. Walker, and E. Ostrom. 2013. Aligning key concepts for global change policy: robustness, resilience, and sustainability. Ecology and Society 18(2): 8. http:// dx.doi.org/10.5751/ES-05178-180208

Anderies, J. M., and M. A. Janssen. 2011. The fragility of robust social-ecological systems. Global Environmental Change 21 (4):1153-1156. http://dx.doi.org/10.1016/j.gloenvcha.2011.07.004

Anderies, J. M., M. A. Janssen, and E. Ostrom. 2003. Design principles for robustness of institutions in social-ecological systems.

Self-published, Indiana University, Bloomington, Indiana, USA.

Anderies, J. M., M. A. Janssen, and E. Ostrom. 2004. A framework to analyze the robustness of social-ecological systems from an institutional perspective. Ecology and Society 9(1): 18. [online] URL: http://www.ecologyandsociety.org/vol9/iss1/art18/.

Arsan, E. L. 2006. Potential for dispersal of the non-native parasite Myxobolus cerebralis: qualitative risk assessments for the State of Alaska and the Willamette River basin, Oregon. Thesis. Oregon State University, Portland, Oregon, USA.

Augerot, X., and C. L. Smith. 2010. Comparative resilience in five North Pacific regional salmon fisheries. Ecology and Society 15 (2): 3. [online] URL: http://www.ecologyandsociety.org/vol15/ iss $2 / \operatorname{art} 3 /$.

Berkes, F., and C. Folke, editors. 1998. Linking social and ecological systems: management practices and social mechanisms for building resilience. Cambridge University Press, Cambridge, UK.
Blomquist, W. 1992. Dividing the waters: governing groundwater in southern California. ICS Press, San Francisco, California, USA.

Bodin, Ö., and M. Tengö. 2012. Disentangling intangible socialecological systems. Global Environmental Change 22(2):430-439. http://dx.doi.org/10.1016/j.gloenvcha.2012.01.005

Carlson, J. M., and J. Doyle. 2002. Complexity and robustness. Proceedings of the National Academy of Sciences 99 (S1):2538-2545.

Carpenter, S. R., and L. H. Gunderson. 2001. Coping with collapse: ecological and social dynamics in ecosystem management. BioScience 51(6):451-457. http://dx.doi. org/10.1641/0006-3568(2001)051[0451:CWCEAS]2.0.CO;2

Colby, B. G. 1995. Regulation, imperfect markets and transaction costs: the elusive quest for efficiency in water allocation. Pages 475-502 in D. W. Bromley, editor. Handbook of environmental economics. Blackwell, Cambridge, UK.

Cone, J., and S. Ridlington. 1996. The Northwest salmon crisis: a documentary history. Oregon State University Press, Corvallis, Oregon, USA.

Coward, E. W., Jr. 1979. Principles of social organization in an indigenous irrigation system. Human Organization 38(1):28-36.

de Moor, M., L. Shaw-Taylor, and P. Warde, editors. 2002. The management of common land in North West Europe, c. 1500-1850. Brepols, Turnhout, Belgium.

Dietz, T., E. Ostrom, and P. C. Stern. 2003. The struggle to govern the commons. Science 302:1907-1912. http://dx.doi.org/10.1126/ science. 1091015

Finlayson, A. C., and B. J. McCay. 1998. Crossing the threshold of ecosystem resilience: the commercial extinction of northern cod. Pages 311-337 in F. Berkes and C. Folke, editors. Linking social and ecological systems: management practices and social mechanisms for building resilience. Cambridge University Press, Cambridge, UK.

Gresh, T., J. Lichatowich, and P. Schoonmaker. 2000. An estimation of historic and current levels of salmon production in the Northeast Pacific ecosystem: evidence of a nutrient deficit in the freshwater systems of the Pacific Northwest. Fisheries 25 (1):15-21. http://dx.doi.org/10.1577/1548-8446(2000)025<0015: AEOHAC $>2.0 . \mathrm{CO} ; 2$

Heal, G. 1998. Valuing the future: economic theory and sustainability. Columbia University Press, New York, New York, USA.

Huntington, C., W. Nehlson, and J. Bowers. 1996. A survey of healthy native stocks of anadromous salmonids in the Pacific Northwest and California. Fisheries 21(3):6-14. http://dx.doi. org/10.1577/1548-8446(1996)021<0006:ASOHNS>2.0.CO;2

Janssen, M. A., and J. M. Anderies. 2007. Robustness trade-offs in social-ecological systems. International Journal of the Commons 1(1):43-66.

Janssen, M. A., J. M. Anderies, and E. Ostrom. 2007. Robustness of social-ecological systems to spatial and temporal variability. Society and Natural Resources 20(4):307-322. http://dx.doi. org/10.1080/08941920601161320 
Kaijser, A. 2002. System building from below: institutional change in Dutch water control systems. Technology and Culture 43(3):521-548. http://dx.doi.org/10.1353/tech.2002.0120

Krupa, M. B., and B. Valcic. 2011. Sustainable fisheries: how externalities impact urban fishery management. Journal of Environmental Studies and Sciences 1(3):159-168. http://dx.doi. org/10.1007/s13412-011-0023-2

Laitos, W. R. 1986. Rapid appraisal of Nepal irrigation systems. Water Management Synthesis Report 43. Colorado State University, Fort Collins, Colorado, USA.

Lam, W. F. 1996. Institutional design of public agencies and coproduction: a study of irrigation associations in Taiwan. World Development 24(6):1039-1054. http://dx.doi.org/10.1016/0305-750X (96)00020-4

Lee, K. N. 1993. Compass and gyroscope: integrating science and politics for the environment. Island Press, Washington, D.C., USA.

Lee, M. 1994. Institutional analysis, public policy, and the possibility of collective action in common-pool resources: a dynamic game theoretic approach. Dissertation. Indiana University, Bloomington, Indiana, USA.

Levin, S. A. 2000. Fragile dominion: complexity and the commons. Perseus, Reading, Massachusetts, USA.

Levin, S. A., and J. Lubchenco. 2008. Resilience, robustness, and marine ecosystem-based management. BioScience 58(1):27-32. http://dx.doi.org/10.1641/B580107

Levine, G. 1977. Management components in irrigation system design and operation. Agricultural Administration 4(1):37-48. http://dx.doi.org/10.1016/0309-586X(77)90031-0

Maass, A., and R. L. Anderson. 1986.... and the desert shall rejoice: conflict, growth, and justice in arid environments. R. E. Krieger, Malabar, Florida, USA.

Martin, E. G., and R. Yoder. 1983. The Cherlung Thulo Kulo: a case study of the farmer-managed irrigation systems. Pages 203-217 in Water management in Nepal: proceedings of the Seminar on Water Management Issues, July 31-Aug. 2. Ministry of Agriculture, Agricultural Projects Servicing Center, Agricultural Development Council, Kathmandu, Nepal.

McGinnis, M. V. 1994. The politics of restoring versus restocking salmon in the Columbia River. Restoration Ecology 2(3):149-155. http://dx.doi.org/10.1111/j.1526-100X.1994.tb00062.x

McGinnis, M. V. 1995. On the verge of collapse: the Columbia River system, wild salmon and the Northwest Power Planning Council. Natural Resources Journal 35(1):63-92.

McHugh, J. L. 1975. Jeffersonian democracy and the fisheries. Pages 134-155 in B. J. Rothschild, editor. World fisheries policy: multidisciplinary views. University of Washington Press, Seattle, Washington, USA.

Moore, M. 1989. The fruits and fallacies of neoliberalism: the case of irrigation policy. World Development 17(11):1733-1750. http://dx.doi.org/10.1016/0305-750X(89)90197-6

National Research Council. 1996. Upstream: salmon and society in the Pacific Northwest. National Academy Press, Washington, D.C., USA.
Nehlsen, W., J. E. Williams, and J. A. Lichatowich. 1991. Pacific Salmon at the crossroads: stocks at risk from California, Oregon, Idaho, and Washington. Fisheries 16(2):4-21. http://dx.doi. org/10.1577/1548-8446(1991)016<0004:PSATCS>2.0.CO;2

Netboy, A. 1980. Salmon: the world's most harassed fish. Winchester Press, Tulsa, Oklahoma, USA.

Ostrom, E. 1990. Governing the commons: the evolution of institutions for collective action. Cambridge University Press, Cambridge, UK.

Ostrom, E. 1999. Self-governance and forest resources. CIFOR Occasional Paper 20. Center for International Forestry Research, Jakarta, Indonesia. [online] URL: http://www.cifor.org/ publications/pdf files/OccPapers/OP-20.pdf.

Ostrom, E. 2002. Common-pool resources and institutions: toward a revised theory. Pages 1315-1339 in B. L. Gardner and G. C. Rausser, editors. Handbook of agricultural economics. Volume 2A: agriculture and external linkages. North-Holland, Amsterdam, The Netherlands.

Ostrom, E. 2005. Understanding institutional diversity. Princeton University Press, Princeton, New Jersey, USA.

Ostrom, E. 2007. A diagnostic approach for going beyond panaceas. Proceedings of the National Academy of Sciences 104 (39):15181-15187. http://dx.doi.org/10.1073/pnas.0702288104

Ostrom, E. 2009. A general framework for analyzing sustainability of social-ecological systems. Science 325 (5939):419-422. http://dx.doi.org/10.1126/science.1172133

Ostrom, E., J. M. Anderies, and M. A. Janssen. 2003. The robustness of multi-level social-ecological systems. In American Political Science Association, 2003 Annual Meeting. American Political Science Association, Washington, D.C., USA. http:// convention2.allacademic.com/one/prol/prol01/index.php? $\mathrm{cmd}=$ Download+Document\&key=unpublished manuscript\&file index=11\&pop up=true\&no click key=true\&attachment style= attachment\&PHPSESSID=ksgspk9uvp7osnfucm 7 mne 7743.

Sarker, T., and T. Itoh. 2001. Design principles in long-enduring institutions of Japanese irrigation common-pool resources. Agricultural Water Management 48(2):89-102. http://dx.doi. org/10.1016/S0378-3774(00)00125-6

Schlüter, M., and C. Pahl-Wostl. 2007. Mechanisms of resilience in common-pool resource management systems: an agent-based model of water use in a river basin. Ecology and Society 12(2): 4. [online] URL: http://www.ecologyandsociety.org/vol12/iss 2/ art4l.

Siy, R. Y., Jr. 1982. Community resource management: lessons from the Zanjara. University of the Philippines Press, Quezon City, Phillipines.

Tang, S. Y. 1992. Institutions and collective action: self-governance in irrigation. Institute for Contemporary Studies Press, San Francisco, California, USA.

U.S. Mayor Newspaper. 2008. Anchorage city salmon program reels in national award. United States Conference of Mayors, Washington, D.C., USA. [online] URL: http://www.usmayors. org/usmayornewspaper/documents/03_10_08/pg4_anchorage.asp. 
Walker, B. H., J. M. Anderies, A. P. Kinzig, and P. Ryan. 2006. Exploring resilience in social-ecological systems: comparative studies and theory development. CSIRO, Victoria, Australia.

Walker, B., C. S. Holling, S. R. Carpenter, and A. Kinzig. 2004. Resilience, adaptability and transformability in social-ecological systems. Ecology and Society 9(2): 5. [online] URL: http://www. ecologyandsociety.org/vol9/iss2/art5/. 